\title{
Sensitivity of diagnostic methods for Mansonella ozzardi microfilariae detection in the Brazilian Amazon Region
}

\author{
Jansen Fernandes Medeiros ${ }^{1 /+}$, Gilberto Fontes ${ }^{2}$, Vilma Lopes do Nascimento ${ }^{3}$, Moreno Rodrigues ${ }^{4}$, \\ Jacob Cohen ${ }^{5}$, Edmar Vaz de Andrade ${ }^{6}$, Felipe Arley Costa Pessoa ${ }^{7}$, Marilaine Martins ${ }^{3}$ \\ ${ }^{1}$ Fundação Oswaldo Cruz-Fiocruz, Laboratório de Entomologia, Porto Velho, RO, Brasil \\ ${ }^{2}$ Universidade Federal de São João Del-Rei, Divinópolis, MG, Brasil \\ ${ }^{3}$ Fundação de Medicina Tropical Dr Heitor Vieira Dourado, Gerência de Parasitologia, Manaus, AM, Brasil \\ ${ }^{4}$ Universidade Federal de Rondônia, Laboratório de Bioecologia de Insetos, Porto Velho, RO, Brasil \\ ${ }^{5}$ Universidade Federal do Amazonas, Departamento de Oftalmologia, Manaus, AM, Brasil \\ ${ }^{6}$ Universidade Federal do Amazonas, Centro de Apoio Multidisciplinar, Manaus, AM, Brasil \\ ${ }^{7}$ Fundação Oswaldo Cruz-Fiocruz, Centro de Pesquisa Leônidas e Maria Deane, Laboratório de Ecologia de Doenças Transmissíveis na \\ Amazônia, Manaus, AM, Brasil
}

BACKGROUND The human filarial worm Mansonella ozzardi is highly endemic in the large tributaries of the Amazon River. This infection is still highly neglected and can be falsely negative when microfilariae levels are low.

OBJECTIVES This study investigated the frequency of individuals with $M$. ozzardi in riverine communities in Coari municipality, Brazilian Amazon.

METHODS Different diagnostic methods including polymerase chain reaction (PCR), blood polycarbonate membrane filtration (PCMF), Knott's method (Knott), digital thick blood smears (DTBS) and venous thick blood smears (VTBS) were used to compare sensitivity and specificity among the methods. Data were analysed using PCMF and Bayesian latent class models (BLCM) as the gold standard. We used BLCM to calculate the prevalence of mansonelliasis based on the results of five diagnostic methods.

FINDINGS The prevalence of mansonelliasis was $35.4 \%$ by PCMF and $30.1 \%$ by BLCM. PCR and Knott methods both possessed high sensitivity. Sensitivity relative to PCMF was 98.5\% [95\% confidence interval (CI): 92.0 - 99.7] for PCR and 83.5\% (95\% CI: 72.9 - 90.5) for Knott. Sensitivity derived by BLCM was 100\% (95\% CI 93.7 - 100) for PCMF, 100\% (95\% CI: 93.7 - 100) for PCR and $98.3 \%$ (95\% CI: 90.6 - 99.9) for Knott. The odds ratio of being diagnosed as microfilaremic increased with age but did not differ between genders. Microfilariae loads were higher in subjects aged 30 - 45 and 45 - 60 years.

MAIN CONCLUSIONS PCMF and PCR were the best methods to assess the prevalence of mansonelliasis in our samples. As such, using these methods could lead to higher prevalence of mansonelliasis in this region than the most commonly used method (i.e., thick blood smears).

Key words: Mansonella ozzardi - mansonelliasis - Solimões River - Bayesian model

The species Mansonella ozzardi is a filarial nematode found exclusively in the neotropical region that extends from southern Mexico to northwestern Argentina, and includes the Caribbean Islands. M. ozzardi causes mansonelliasis. In Brazil, this parasite is highly prevalent in riverine and indigenous communities in Amazonas state, particularly in the regions of the Solimões, Purus and Negro rivers and their tributaries (Lacerda \& Rachou 1956, Batista et al. 1960a, Medeiros et al. 2008, 2009, 2011, Martins et al. 2010). The filariasis caused by M. ozzardi has a symptomatology that is not well defined. In some cases this filariasis can be confused with malaria, especially in areas where the two diseases overlap (Martins et al. 2010). Symptoms include fever, chills, headache and joint pain, and the disease may be associated with ocular damage with or without corneal lesions (Batista et al. 1960b, Cohen et al. 2008, Vianna et al. 2012).

doi: 10.1590/0074-02760170321

Financial support: FAPEAM

+ Corresponding author: jmedeiro@gmail.com

Received 07 August 2017

Accepted 17 November 2017
The oligosymptomatic nature of infection, negligence of treatment and a high incidence of vector bites have contributed to the high prevalence rate of this filariasis (Lacerda \& Rachou 1956, Medeiros et al. 2009, 2011). Lacerda and Rachou (1956) recorded a $10.0 \%$ prevalence rate in riverine communities in Coari municipality, and a prevalence rate of 7.1 to $17.8 \%$ in Tefé municipality; both are located in the middle Solimões River region. Recent studies have reported a prevalence rate of $18.4 \%$ in Coari and $16.3 \%$ in Tefé (Martins et al. 2010, Medeiros et al. 2014). In addition, the epidemiological profile of mansonelliasis has changed: mansonelliasis has spread from rural to urban environments, and is now an emerging disease in mid-size cities in Amazonas state (Martins et al. 2010).

The thick blood smear has been the most common diagnostic method used in mansonelliasis studies conducted in Amazonas state (e.g., Batista et al. 1960a, Medeiros et al. 2008, 2009, 2011, Martins et al. 2010). Other methods, such as Knott's method (Knott) and polycarbonate membrane blood filtration (PCMF), have been used for diagnosis in a few epidemiological surveys (Moraes 1958, Batista et al. 1960a, Adami et al. 2014, Basano et al. 2016), and have also been used to monitor 
the effects of ivermectin in the treatment of microfilaremia (Basano et al. 2014). Medeiros et al. (2015) showed that overall $M$. ozzardi prevalence estimates based on polymerase chain reaction (PCR) from venous blood or the $\mathrm{FTA}^{\circledR}$ card were 1.5 to 1.8 times higher than estimates made using microscopy to examine peripheral finger-prick blood samples.

The objective of this study was to determine the frequency of microfilaremics in riverine communities in Coari municipality, and to assess the sensitivity of different diagnostic methods used for the detection of $M$. ozzardi microfilariae.

\section{MATERIALS AND METHODS}

Study area - This study was conducted in riverine communities in the municipality of Coari $\left(4^{\circ} 05^{\prime} \mathrm{S}\right.$ $63^{\circ} 08^{\prime} \mathrm{W}$ ), Amazonas state, Brazil (Fig. 1). Coari is located in the middle Solimões River in southwestern Amazon, about $450 \mathrm{~km}$ from Manaus. The survey was conducted in October 2010. At the time, Coari had an estimated population of 75, 965 [urban population $=49$, $638(65.4 \%)$, rural $=26,271(34.6 \%)]$ with the population estimated to increase to 83,078 by 2015 (IBGE 2010). The survey was conducted by means of a convenience sample that included 189 residents (aged 6 to 77 years) of five small communities along the Solimões River. The study was approved by the Ethical Committee of the Fundação de Medicina Tropical Heitor Vieira Dourado (Protocol no. 2283/04). Informed written consent was obtained from all adults and from the parents or guardians of all children less than 18 years of age.

Laboratory methods - Blood samples were collected by digital puncture for diagnosis using thick blood smears and by venous puncture for diagnosis using Knott, PCMF, PCR and venous thick blood smears (VTBS).

Digital thick blood smears (DTBS) and VTBS - Three drops of blood (approximately $80 \mu \mathrm{L}$ ) were collected on a glass slide, spread out and dried at room temperature. After $10 \mathrm{~h}$, the thick blood smears were lysed with water for $10 \mathrm{~min}$, fixed with methanol and stained with Giemsa.

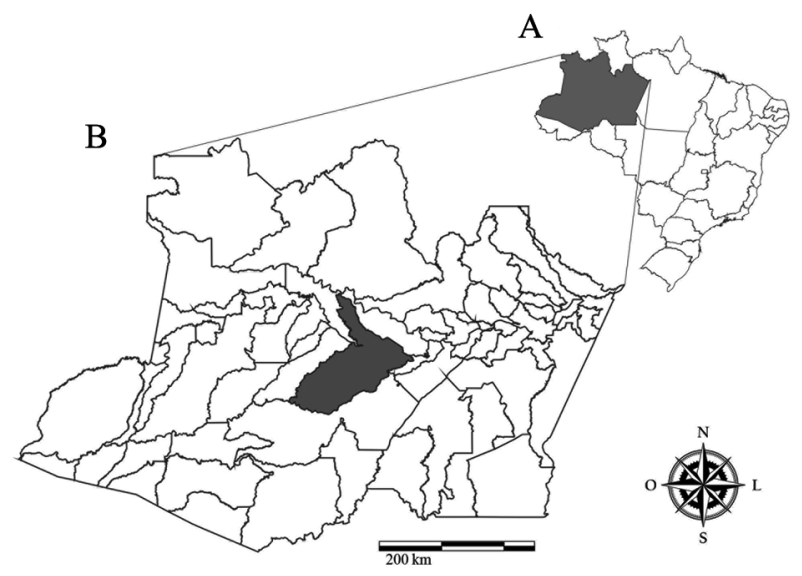

Fig. 1: (A) map of Brazil with emphasis on the state of Amazonas. (B) Location of the study area, municipality of Coari, Amazonas state, Brazil.
PCMF of blood - One millilitre of venous blood from each patient was diluted in $0.9 \%$ physiological saline solution and filtered in a polycarbonate membrane with pores measuring $3 \mu \mathrm{m}$ in diameter. The membranes were then fixed with methanol and placed on Giemsa-stained glass slides. PCMF was the gold standard method in this study, because this technique has demonstrated higher sensitivity for M. ozzardi diagnosis (Botto et al. 1983, Vera et al. 2011, Basano et al. 2016).

Knott - One milliliter of venous blood from each patient was diluted in $9 \mathrm{~mL}$ of $2 \%$ formalin and centrifuged at 2,000 rpm for $10 \mathrm{~min}$. The supernatant was removed and the pellet washed with $2 \%$ formalin. The pellet was placed on a slide, fixed with methanol and stained with Giemsa. All slides were observed under light microscopy (200X and 400X) and microfilariae (mf) were counted.

$P C R$ - The microfilariae DNA was extracted following the PROMEGA ${ }^{\circledR}$ kit protocol (Promega, Madison, WI, USA). Identification of the filarial species was performed using nested PCR with two PCR reactions. The first reaction incorporated the primers rRNA2 and NC2, in $18 \mathrm{~S}$ and 28S ribosomal DNA (rDNA), respectively, to amplify the ITS1-5.8S-ITS2 fragment from total nematode DNA and yield a 1097bp product (Nuchprayoon et al. 2005). The second reaction incorporated the products of the first reaction together with the primers FL1-F (5'-TTCCGTAGGTGAACCTGC-3') and Di660R (5'-ACCCTCAACCAGACGTAC-3') in $18 \mathrm{~S}$ and $28 \mathrm{~S}$ ribosomal DNA (rDNA), respectively, to yield a $552 \mathrm{bp}$ product which indicates the presence of $M$. ozzardi. Forward and reverse oligonucleotide primers were designed based on filarial parasite $18 \mathrm{~S}$ and $5.8 \mathrm{~S}$ rDNA conserved sequences, as previously described by Nuchprayoon et al. (2005). PCRs were performed in a $25 \mu \mathrm{L}$ reaction mixture containing $20 \mathrm{mM}$ Tris- $\mathrm{HCl}$ (pH 8.4), $1.5 \mathrm{mM} \mathrm{MgCl}, 50 \mathrm{mM} \mathrm{KCl}$, $0.2 \mathrm{mM}$ of dNTPs, 1 unit of Taq DNA polymerase and 0.5 $\mu \mathrm{M}$ of each primer. The ITS1 forward primer (ITS1-F) was 5'-GGTGAACCTGCGGAAGGATC-3' and the ITS1 reverse primer (ITS1-R) was 5'-GCGAATTGCAGACGCATTGAG-3' (PCR reaction cycle: $94^{\circ} \mathrm{C}$ for $5 \mathrm{~min}$; 40 cycles at $94^{\circ} \mathrm{C}$ for $30 \mathrm{~s}-58^{\circ} \mathrm{C}$ for $30 \mathrm{~s}-72^{\circ} \mathrm{C}$ for $90 \mathrm{~s}$; and $7 \mathrm{~min}$ at $72^{\circ} \mathrm{C}$ ). All oligonucleotide primers were obtained from the Alpha DNA (http://www.alphadna.com/ contact.html Montreal, Quebec, Canada).

Statistical analyses - To construct the reference group (gold standard), the results of five diagnostics in a Bayesian latent class model (BLCM) were used. The BLCM is a statistical method for finding subgroups within a multivariate dataset. This method does not assume that the diagnosis of mansonelliasis can be confirmed by only one test. Instead, the diagnosis of mansonelliasis is determined by the pattern of association between the results of all five tests (Turecheck et al. 2013). We chose the model based on deviance criterion information (DIC), degrees of freedom (DF) and the maximum likelihood (ML). We used the best-fitted model to calculate the prevalence of mansonelliasis among subjects and calculated the sensitivity and specificity of all five tests. Furthermore, sensitivity, specificity and negative predictive value (NPV) also were calculated using membrane filtration as the 
gold standard. The BLCM was constructed using the BayesLCA package (White \& Murphy 2014).

Logistic regression was used to compute the odds ratio $(\mathrm{OR})$ and the probability of returning a positive result according to the quantity of microfilariae present in the sample. We performed all analyses on R 3.2.3 software (R Core Team 2015). All the models were submitted to residual analysis to check viability.

\section{RESULTS}

From a total of 189 samples, the PCMF gold standard detected 67 samples (35.4\%) that were positive for M. ozzardi microfilariae. PCR and Knott exhibited high sensitivity, detecting $66(98.5 \%)$ and $56(83.5 \%)$ positive samples, respectively. The DTBS and VTBS methods detected $51(76.1 \%)$ and $47(70.1 \%)$ positive samples, respectively. DTBS, VTBS and Knott showed a specificity of $100 \%$, and there were no false negatives. PCR showed a specificity of $97.6 \%$, indicating that there were false negatives.

Using BLCM we constructed two groups: (i) mansonelliasis and (ii) non-monsonelliasis. Both groups were constructed indirectly by the results of five diagnosis tests for mansonelliasis. According to these results, mansoneliasis prevalence in the samples was $30.1 \%$ (95\% CI 26.6 - 33.6). When we use the mansonelliasis group to individually assess sensitivity, specificity and VPN of each test, we found that PCMF was the best test to identify a patient with mansonelliasis $(100 \%$ sensitivity; $95 \%$ CI 93.7 - 100) followed by Knott $(98.3 \%$; $95 \%$ CI 90.6 - 99.9) and PCR (100\%; 95\% CI 93.7 - 100) (Table).

The probability of a positive result was altered by the quantity of microfilariae (quantified by PCMF) per $\mathrm{mL}$ of sample. The OR of returning a positive result by digital blood smear increased on average by a factor of 1.03 (95\% CI 1.01 - 1.04) for an increase of one microfilariae per $\mathrm{mL}$ of sample. The same pattern was found for VTBS (1.02; 95\% CI 1.01 - 1.03), Knott (1.0; 95\% CI 1.03 - 1.08) and PCR (3.97; 95\% CI 2.28 - 10.13).

The quantity of microfilariae necessary to return a positive result was lower using PCR than for any other test: samples with more than eight microfilariae returned a positive result with $100 \%$ certainty. By contrast, when using DTBS, which is the most common diagnostic method, a sample with approximately 50 microfilariae per $\mathrm{mL}$ returned a positive result only $50 \%$ of the time, the equivalent of a coin toss (Fig. 2).

TABLE

Sensitivity, specificity and negative predictive values of the different diagnostic tests

\begin{tabular}{|c|c|c|}
\hline & Membrane as gold standard \% (95) & BLCM \%(95) \\
\hline Frequency of microfilaremics & $35.4(29.0-42.0)$ & $30.1(26.6-33.6)$ \\
\hline \multicolumn{3}{|l|}{ Polymerase chain reaction } \\
\hline Sensitivity & $98.5(92.0-99.7)$ & $100(93.7-100)$ \\
\hline Specificity & $97.6(93.2-99.2)$ & $91.7(85.9-95.6)$ \\
\hline NPV & $99.2(95.5-99.8)$ & \\
\hline \multicolumn{3}{|c|}{ Blood filtration in polycarbonate membrane } \\
\hline Sensitivity & - & $100(93.7-100)$ \\
\hline Specificity & - & $100(93.7-100)$ \\
\hline \multicolumn{3}{|l|}{ NPV } \\
\hline \multicolumn{3}{|l|}{ Knott } \\
\hline Sensitivity & $83.5 \%(72.9-90.5)$ & $98.3(90.6-99.9)$ \\
\hline Specificity & $100 \%(96.9-100)$ & $100(97.2-100)$ \\
\hline NPV & $91.7 \%(85.8-95.3)$ & \\
\hline \multicolumn{3}{|l|}{ Digital thick blood smears } \\
\hline Sensitivity & $76.1 \%(64.6-84.7)$ & $89.5(89.5-96.0)$ \\
\hline Specificity & $100 \%(96.9-100)$ & $100(97.2-100)$ \\
\hline NPV & $88.4 \%(82.1-92.7)$ & \\
\hline \multicolumn{3}{|l|}{ Venous thick blood smears } \\
\hline Sensitivity & $70.1 \%(58.3-79.8$ & $82.5(82.5-91.3)$ \\
\hline Specificity & $100 \%(96.9-100)$ & $100(97.2-100)$ \\
\hline NPV & $85.9 \%(79.2-90.7)$ & \\
\hline
\end{tabular}

*: tests used were digital thick blood smear (DTBS), venous thick blood smear (VTBS), polycarbonate membrane filtration (PCMF), Knott's method (Knott) and polymerase chain reaction (PCR); **: PCMF was used as the gold standard. The results of the five diagnoses were analysed using the Baynesian latent class model (BLCM). 

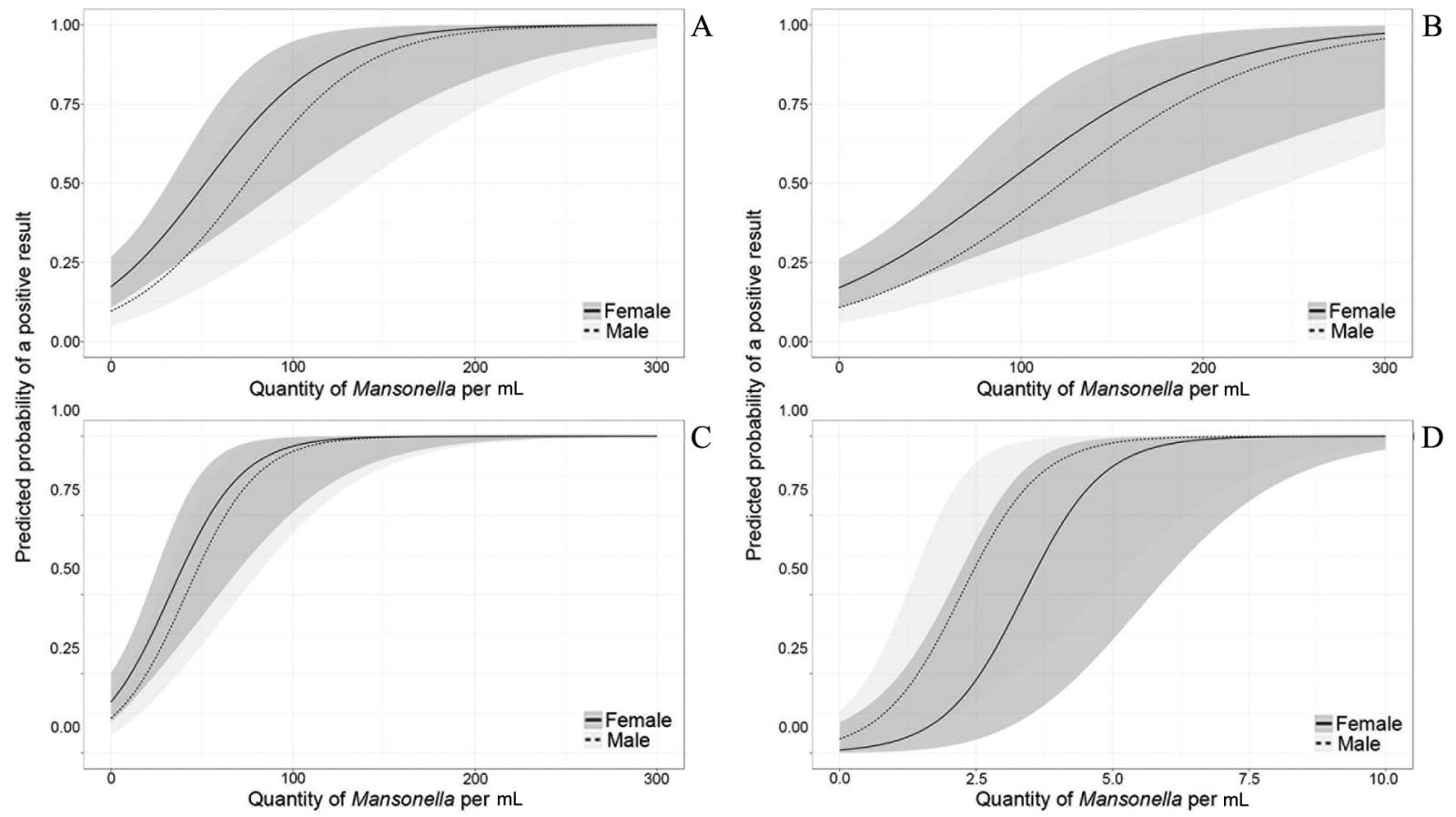

Fig. 2: predicted probability of returning a positive result for Mansonella ozzardi in (A) digital thick blood smear, (B) venous thick blood smear, (C) Knott, and (D) polymerase chain reaction according to the quantity of microfilariae per mL quantified using polycarbonate membrane filtration of blood.

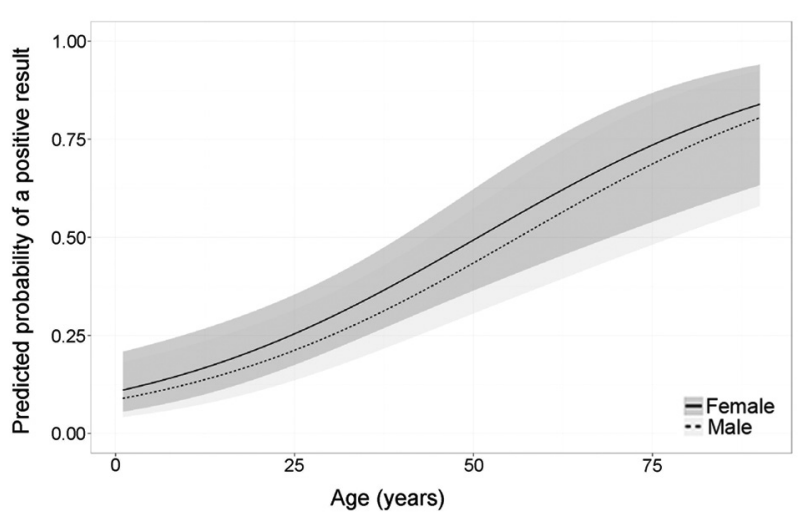

Fig. 3: predicted probability and confidence interval of being infected by Mansonella ozzardi according to age and gender.

This pattern of infection and diagnosis exhibited no statistical difference between genders $(p>0.05)$. The gender-adjusted (gender-adjusted OR) of a positive diagnosis increased by $1.04(1.02-1.06)$ for every year that a patient's age increased (Fig. 3).

\section{DISCUSSION}

This is the first study of M. ozzardi in Brazil to use five diagnostic methods simultaneously and observe greater sensitivity in the PCMF, PCR and Knott methods. A few studies in Brazil have used more than one diagnostic method for identifying $M$. ozzardi. Moraes (1958) and Batista et al. (1960a) observed higher prevalence rates with the Knott diagnoses $(41.4 \%$ and $56.7 \%$, respectively) in relation to DTBS diagnoses (23.1\% and
$30.3 \%$, respectively). It has been recently observed that PCR is 1.8 times more effective than DTBS for diagnosing the presence of M. ozzardi (Medeiros et al. 2015). There are also reports of low DTBS sensitivity in other countries. In Haiti, a higher prevalence of microfilaremics was detected by Knott (30.3\%) in comparison to DTBS (24.1\%) (Raccurt et al. 1982). In Venezuela, the PCMF and Knott prevalence rates were $41.2 \%$ and $36.7 \%$, respectively, whereas DTBS exhibited far less sensitivity, detecting a prevalence rate of only $12.2 \%$ (Botto et al. 1983). The main diagnostic method used in the Amazon basin is DTBS. This study corroborates earlier findings that DTBS possesses less sensitivity than other diagnostic methods, and that the prevalence rates are therefore more likely to be underreported when DTBS is the method of diagnosis. Presently, the probability of underreporting prevalence was $1.35(69 / 51)$ times lower for PCR, 1.31 (67/51) times lower for PCMF and 1.09 (56/51) times lower for Knott.

Microfilariaemia influences the probability that a given test will return a positive result. As the number of microfilariae in a sample increases the probability that a given test will return a positive result increases. Therefore, in regions where parasitized individuals have peripheral blood with low microfilariaemia, prevalence estimates are likely to be underreported when thick blood smears are the only method used for diagnosis. Moulia-Pelat et al. (1992) observed that the DTBS method detected only $44 \%$ (30/69) of microfilaremics with low and ultra-low microfilariae densities, and they concluded that DTBS was not reliable when a concentration method was used for diagnoses. Difference in sensitivity has also been reported in the diagnosis of Wuchereria 
bancrofti; the difference in sensitivity between thick blood smears and PCMF was small in patients with a microfilariae density above $33 \mathrm{mf} / \mathrm{mL}$, but PCMF sensitivity was higher when microfilariaemia density was below $33 \mathrm{mf} / \mathrm{mL}$ (Kimura et al. 1984). In this study, DTBS detected only $66.7 \%$ of the microfilaremics detected by PCMF when samples had a density of $50 \mathrm{mf} / \mathrm{mL}$ or less.

The highest density of microfilariae was observed in subjects aged 30 - 45 and 45 - 60 years. Microfilariae may accumulate in older individuals because daily activities, such as farming and fishing, may expose these individuals to vectors more frequently and therefore lead to more frequent infection (Batista et al. 1960a, Medeiros et al. 2009, Martins et al. 2010). It is possible that a high degree of exposure could lead an individual to acquire the infection more than once, or to be parasitized by multiple females continuously producing microfilariae at high densities. An increase in microfilariae density with age was also observed by Botto et al. (1983), who recorded densities of $1.93 \mathrm{mf} / \mathrm{mL}$ in subjects $0-9$ years of age and $192.3 \mathrm{mf} / \mathrm{mL}$ in subjects older than 50 years of age.

Most of the research on M. ozzardi conducted in Amazonas State, Brazil, has used thick blood smears for diagnosis. It is therefore highly likely that the prevalence rate of mansonelliasis has been underreported in several regions, especially regions where individuals exhibit low microfilariae density. This study addresses the problem of underreported infection by demonstrating that prevalence rates can be assessed more accurately using more sensitive diagnostic methods, such as Knott, PCMF and PCR.

\section{AUTHORS' CONTRIBUTION}

JC - participated in the design of the study and provided infrastructure for the study; MM, GF, EVA, FACP and JFM - collected the samples, performed in laboratory diagnostics and wrote the manuscript; MSR - analysis of the data; VLN performed molecular biological assays.

\section{REFERENCES}

Adami YL, Rodrigues G, Alves MC, Moraes MAP, Banic DM, MaiaHerzog M. New records of Mansonella ozzardi: a parasite that is spreading from the state of Amazonas to previously uninfected areas of the state of Acre in the Purus River region. Mem Inst Oswaldo Cruz. 2014; 109(1): 87-92.

Basano SA, Fontes G, Medeiros JF, Camargo JSAA, Vera LJS, Araujo MPP, et al. Sustained clearance of Mansonella ozzardi infection after treatment with Ivermectin in the Brazilian Amazon. Am J Trop Med Hyg. 2014; 90(6): 1170-5.

Basano SA, Medeiros JF, Fontes G, Vieira GD, Camargo JSAA, Vera LJS, et al. Occurrence of Mansonella ozzardi diagnosed using a polycarbonate membrane in a riverside population of Lábrea in the Western Brazilian Amazon. Rev Soc Bras Med Trop. 2016; 49(1): 115-8.

Batista D, Cerqueira NL, Moraes MAP. Epidemiologia da mansonelose em localidade do interior do Amazonas. Rev Assoc Med Bras. 1960a; 6: 176-84.

Batista D, Oliveira WR, Rabello VD. Estudo da patogenicidade da Mansonella ozzardi e da sintomatologia da mansonelose. Rev Inst Med Trop São Paulo. 1960b; 2(5): 281-9.

Botto C, Yarzabal A, Lugo E, Arango M, Yarzabal L. Aspectos epidemiológicos de la mansonelosis en el Território Federal Amazonas, Venezuela. In lãs filariosis humanas en el Território Federal do Amazonas (Venezuela). Editorial Proicet Amazonas. Publ Cient. 1983; 2: 21-40.
Cohen JM, Ribeiro JAS, Martins M. Acometimento ocular em pacientes com mansonelose. Arq Bras Oftalmol. 2008; 71(2): 167-71.

IBGE - Instituto Brasileiro de Geografia e Estatística 2010. Censo 2008 - População e domicílios. 2010. Available from: www.ibge.gov.br/.

Kimura E, Penaia I, Spears GF. Comparison of methods for the detection of microfilariae of Wuchereria bancrofti in Western Samoa. Southeast Asian J Trop Med Public. 1984; 15(2): 767-74.

Lacerda NB, Rachou RG. Filarioses humanas nas sedes municipais do estado do Amazonas e territórios do Acre, Guaporé e Rio Branco. Rev Bras Malariol Doenças Trop. 1956; 8(3): 437-42.

Martins M, Pessoa FAC, de Medeiros MB, de Andrade EV, Medeiros JF. Mansonella ozzardi in Amazonas, Brazil: prevalence and distribution in the municipality of Coari, in the middle Solimões River. Mem Inst Oswaldo Cruz. 2010; 105(3): 246-53.

Medeiros JF, Almeida TAP, Silva LBT, Rubio JM, Crainey JL, Pessoa FAC, et al. A field trial of a PCR-based Mansonella ozzardi diagnosis assay detects high-levels of submicroscopic $M$. ozzardi infections in both venous blood samples and FTA ${ }^{\circledR}$ card dried blood spots. Parasit Vectors. 2015; 8: 280.

Medeiros JF, Py-Daniel V, Barbosa UC, Izzo TJ. Mansonella ozzardi in Brazil: prevalence of infection in riverine communities in the Purus region, in the state of Amazonas. Mem Inst Oswaldo Cruz. 2009; 104: 74-80.

Medeiros JF, Py-Daniel V, Barbosa UC, Ogawa GM. Current profile of Mansonella ozzardi (Nematoda: Onchocercidae) in communities along the Ituxi river, Lábrea municipality, Amazonas, Brazil. Mem Inst Oswaldo Cruz. 2008; 103(4): 409-11.

Medeiros JF, Py-Daniel V, Barbosa UC. Prevalence of Mansonella ozzar$d i$ among riverine communities in the municipality of Lábrea, Amazonas state, Brazil. Rev Soc Bras Med Trop. 2011; 44(2): 186-90.

Medeiros JF, Rodrigues MS, Katsuragawa TH, Costa CA, Pessoa FAC. Mansonella ozzardi in the municipality of Tefé, Amazonas, Brazil, 60 years after the first report: an epidemiologic study. Mem Inst Oswaldo Cruz. 2014; 109(4): 480-3.

Moraes MAP. Contribuição ao estudo da mansonelose do Amazonas. O Hospital. 1958; 54(6): 887-92.

Moulia-Pelat JP, Glaziou P, Nguyen-Ngoc L, Cardines D, Spiegel A, Cartel JL. A comparative study of detection methods for evaluation of microfilaremia in lymphatic filariasis control programmes. Trop Med Parasitol. 1992; 43(3): 146-8.

Nuchprayoon S, Junpee A, Poovorawan Y, Scott AL. Detection and differentiation of filarial parasites by universal primers and polymerase chain. Am J Trop Med Hyg. 2005; 73(5): 895-900.

R Core Team 2015. R: a language and environment for statistical computing. R Foundation for Statistical Computing, Vienna, Austria. 2015. Available from: https://www.R-project.org/.

Raccurt C, Lowrie R, Bancy J, Katz S. Mansonella ozzardi in Haiti. III. A comparision of the sensitivity of four sampling methods in detecting infection. Am J Trop Med Hyg. 1982; 31(2): 275-9.

Turechek WW, Webster CG, Duan J, Roberts PD, Kousik CS, Adkins $\mathrm{S}$. The use of latent class analysis to estimate the sensitivities and specificities of diagnostic tests for Squash vein yellowing virus in cucurbit species when there is no gold standard. Phytopathology. 2013; 103(12): 243-51.

Vera LJ, Basano SA, Camargo JS, França AK, Casseb AA, Medeiros $\mathrm{JF}$, et al. Improvement of a PCR test to diagnose infection by Mansonella ozzardi. Rev Soc Bras Med Trop. 2011; 44(3): 380-2.

Vianna LMM, Martins M, Cohen MJ, Cohen JM, Belfort Jr R. Mansonella ozzardi corneal lesions in the Amazon: a cross-sectional study. BMJ Open. 2012; 2: e001266.

White A, Murphy TB. Bayes LCA: an R Package for Bayesian latent class. J Stat Softw. 2014; 61(13): 1-28. 